Dominik Maślach ${ }^{1}$, Justyna Markiewicz, Alina Warelis², Michalina Krzyżak ${ }^{3}$

\title{
IMPORTANCE OF FINANCIAL LIQUIDITY IN HOSPITAL MANAGEMENT
}

\section{ZNACZENIE PŁYNNOŚCI FINANSOWEJ W ZARZĄDZANIU SZPITALEM}

\author{
${ }^{1}$ Department of Public Health, Medical University of Bialystok \\ ${ }^{2}$ Vocational State College prof. Edward F. Szczepanik in Suwalki \\ ${ }^{3}$ Department of Hygiene, Epidemiology and Ergonomics, Medical University of Bialystok \\ ${ }^{1}$ Zakład Zdrowia Publicznego, Uniwersytet Medyczny w Białymstoku \\ ${ }^{2}$ Państwowa Wyższa Szkoła Zawodowa im. prof. Edwarda F. Szczepanika w Suwałkach \\ ${ }^{3}$ Zakład Higieny, Epidemiologii i Ergonomii, Uniwersytet Medyczny w Białymstoku
}

\begin{abstract}
INTRODUCTION: Financial liquidity management in hospitals is of great importance in ensuring access to medical care and continuity of health care service provision. It is one of the management's biggest challenges, which the possibility to conduct health care activity depends on.

OBJECTIVE: The objective of this study was to assess the financial liquidity of public hospitals, based on the example of public hospitals in Podlaskie Voivodeship in years 2013-2017.

MATERIALS AND METHODS: Revenues, expenses and financial performance levels were analysed and financial liquidity was evaluated with reference to current and quick ratios.

Public hospitals, whose founding entity is the Podlaskie Voivodeship Self-government, were selected for the study. The assessment of the financial situation was based on the data from the hospitals' financial statements for years 2013-2017. The assessment was made with a special reference to financial liquidity.

RESULTS: In years 2013-2017, a steady increase of revenues and expenses was observed in the case-study hospitals. The general financial performance of these entities improved significantly. During the assessment period, the current ratio in the hospitals was average, exceeding the optimal value. In the first hospital group (number of beds $>250$ ), the current ratio was below the optimal values (except for 2016). The second hospital group (number of beds $<250$ ) was characterised by liquidity ratios above the optimal value.

CONCLUSIONS: Management of financial liquidity in hospitals, aimed at maintaining financial liquidity at optimal level, should be the management's priority action when managing the finances of a health care entity. These actions should be multi-directional and based on information about the financial situation of the hospitals and on the hospital's ratio analysis, which is vital for the management's decision making.
\end{abstract}

Key words: public health, health economics, financial liquidity, financial management

\section{STRESZCZENIE}

WSTĘP. Zarządzanie płynnością finansową w szpitalach ma ogromne znaczenie dla zapewnienia dostępności opieki medycznej i ciągłości udzielania świadczeń zdrowotnych. Jest jednym z największych wyzwań kadry zarządzającej, od którego zależy możliwość prowadzenia działalności leczniczej.

CEL. Celem pracy była ocena płynności finansowej szpitali publicznych, na przykładzie szpitali publicznych w województwie podlaskim w latach 2013-2017.

MATERIAŁ I METODY. Dokonano analizy poziomu przychodów, kosztów oraz wyników finansowych, a także oceniono płynność finansową z uwzględnieniem wskaźnika płynności bieżącej oraz wskaźnika płynności szybkiej.

Do badania wytypowano szpitale publiczne, dla których podmiotem tworzącym jest Samorząd Województwa Podlaskiego. Do oceny sytuacji finansowej, ze szczególnym uwzględnieniem płynności finansowej, wykorzystano informacje zawarte w sprawozdaniach finansowych szpitali w latach 2013-2017.

(C) National Institute of Public Health - National Institute of Hygiene / Narodowy Instytut Zdrowia Publicznego - Państwowy Zakład Higieny 
WYNIKI. W latach 2013-2017 obserwowano systematyczny wzrost przychodów i kosztów w szpitalach objętych analizą. Wynik finansowy ogółem tych podmiotów uległ znacznej poprawie. Szpitale wykazywały w ocenianym okresie wartości średnie wskaźnika bieżącej płynności, powyżej wartości optymalnych. Pierwsza grupa szpitali (liczba łóżek>250) osiągnęła wartości wskaźnika bieżącej płynności poniżej wartości optymalnych (za wyjątkiem 2016 r.). Druga grupa szpitali (liczba łóżek<250) charakteryzowała się wartościami wskaźników płynności finansowej powyżej wartości optymalnej.

WNIOSKI. Zarządzanie płynnością finansową w szpitalu, w celu utrzymania płynności finansowej na optymalnym poziomie, powinno być priorytetowym działaniem kadry zarządzającej w zakresie zarządzania finansami podmiotu leczniczego. Działania te powinny być wielokierunkowe i oparte na informacji o sytuacji finansowej oraz analizie wskaźnikowej szpitala, niezbędnej do podejmowania decyzji zarządczych.

Słowa kluczowe: zdrowie publiczne, ekonomika zdrowia, plynność finansowa, zarządzanie finansami

\section{INTRODUCTION}

The inpatient (hospital) care due to the performed functions and its capital-intensive nature occupies one of the most important positions in the health care system. In most countries in the world, the biggest part of the resources is absorbed to satisfy the society's health necessities (1). In Poland in 2018, PLN $42,110,915$ from the National Health Fund (NFZ) was allocated to the hospital treatment; that is $52 \%$ of the financial resources for the procurement by the public health care services' payer - figure 1.

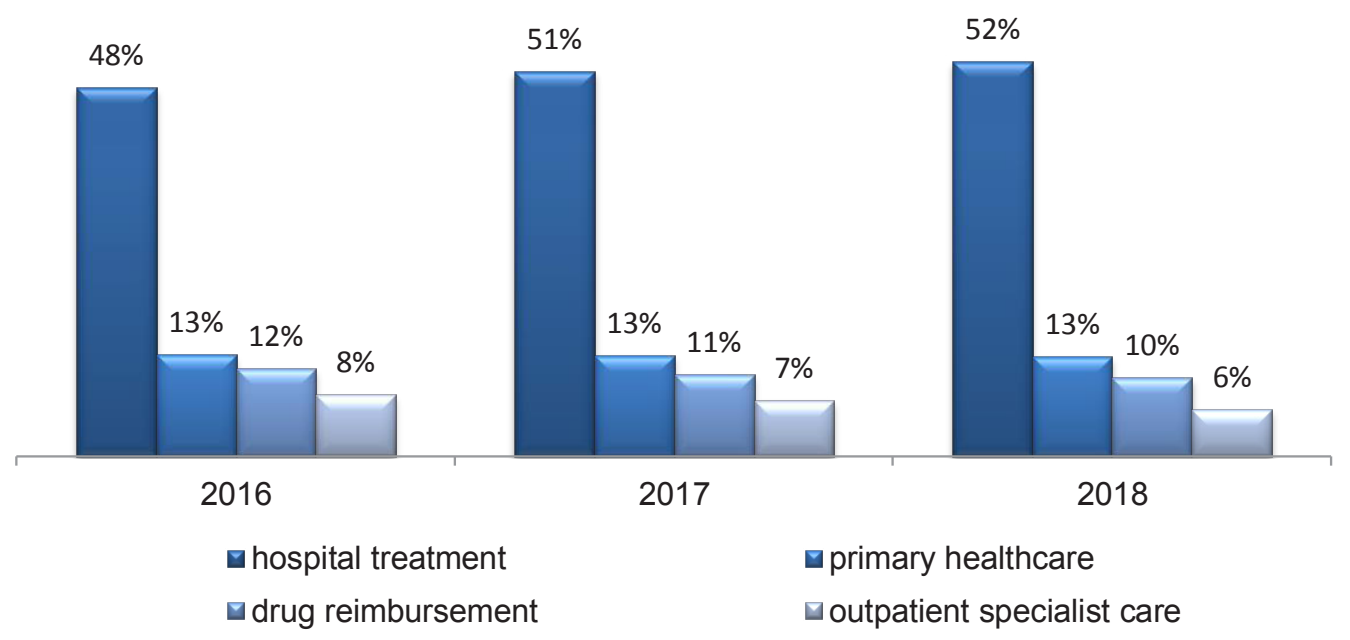

Fig. 1. The structure of NFZ expenditure on the purchase of healthcare services in 2016-2018

Ryc. 1. Struktura wydatków NFZ na zakup świadczeń opieki zdrowotnej w latach 2016-2018

Source: Own study based on the NFZ financial plans for 2016-2018 (2).

Źródło: Opracowanie własne na podstawie planów finansowych NFZ na lata 2016-2018 (2).

A hospital is a health care institution characterised by its constant readiness to admit, place and provide patients with round-the-clock, comprehensive and qualified medical care that implies observation, diagnosis, care and treatment (3).

Currently, health care entities are constrained to operate in an extremely complex environment and dynamically changing conditions. The expenses of medical service provision are growing due to an increasing life expectancy, which in turn leads

\section{WSTĘP}

Lecznictwo stacjonarne (szpitalne) ze względu na pełnione funkcje i kapitałochłonność jest jedną z najważniejszych pozycji w systemie opieki zdrowotnej. W większości państw świata absorbuje największą część zasobów przeznaczonych na zaspokojenie potrzeb zdrowotnych społeczeństwa (1). W Polsce w 2018 roku na leczenie szpitalne przeznaczono ze środków Narodowego Funduszu Zdrowia (NFZ) 42.110 .915 zk, tj. 52\% środków finansowych na zakup przez publicznego płatnika świadczeń opieki zdrowotnej - rycina nr 1.

Szpital jest zakładem opieki zdrowotnej, którego cechą charakterystyczną jest stała gotowość przyjęcia, umieszczenia i zapewnienia pacjentowi całodobowej, wszechstronnej i kwalifikowanej opieki medycznej, polegającej na obserwacji, rozpoznaniu, pielęgnowaniu i leczeniu (3).

Obecnie podmioty lecznicze zmuszone są do działania w niezwykle złożonym otoczeniu i dynamicznie zmieniających się warunkach. Wzrastają wydatki na świadczenie usług medycznych, ponieważ wydłuża się oczekiwana długość życia, a w związku z tym wzrasta liczba osób star- 
to an increase in the number of elderly people. An increase in the incidence of chronic diseases, whose treatment requires considerable financial resources, is a consequence of such changes. The increased expenditure results also from the development of medical technology (4). Additionally, health care entities perform tasks related to health promotion, prevention and development of health-conscious attitude in the society. There is no doubt that this additional challenge, related to the role of restorative medicine, results from the definition of health promoted by the World Health Organisation (WHO). According to this definition, health is understood as a state of complete physical, mental, and social wellbeing, and not merely the absence of disease. Financial resources for the above mentioned goals are limited and the demands of health care users should motivate the system organisers to look for new, more effective solutions (5).

Hospitals operate in a sector that is constantly subject to change due to implementation of health care reforms, changes in the funding schemes and introduction of new legal provisions (3). On 15 July 2019, the Law of 10 June 2016 amending the Law on health care activity and some other certain laws came into force (Journal of Laws 2016, item 960). Among the new provisions of the Law there were some additional obligations related to the financial management that were assigned to the independent public health centre's director. On 31 May of each year, the director of the independent public health care centre prepares a report on the economic and financial situation of the independent public health care centre and submits it to the founding entity. The report is elaborated based on financial statements for the previous financial year. It includes an analysis of the economic and financial situation and a forecast for the situation for the next three financial years together with a description of the assumptions made and information on significant events that affect the independent public health care centre's financial situation. The analyses and forecasts are elaborated based on economic and financial ratios that have been specified in the Regulation of the Minister of Health of 12 April 2017 on economic and financial ratios necessary for the analysis and forecast of independent public health care centres' economic and financial situation (Journal of Laws 2017, item 832). The main objective of implementing homogeneous financial ratios for all health care entities is to ensure transparency and comparability of the results. The founding entity evaluates the economic and financial situation of the independent public health care centre based on the previously mentioned report. This is intended to increase the efficiency of the ongoing control of the health care entities' financial situation and enable a more prompt reaction to change. szych. Konsekwencją tych zmian jest wzrost zachorowalności na choroby przewlekłe, których leczenie wymaga znacznych nakładów finansowych. Ponadto ponoszenie coraz większych nakładów wynika z rozwoju technologii medycznych (4). Dodatkowo podmioty lecznicze realizują zadania z zakresu promocji zdrowia, profilaktyki chorób oraz rozwoju prozdrowotnych postaw społeczeństwa. Nie ulega wątpliwości, że to dodatkowe wyzwanie w stosunku do roli medycyny naprawczej wynika z propagowanej przez Światową Organizację Zdrowia (WHO) definicji zdrowia. Wedhug powyższej definicji zdrowie jest pojmowane, jako pełen dobrostan fizyczny, psychiczny, społeczny, a nie tylko sam brak choroby. Środki finansowe na powyższe cele są ograniczone, a wymagania korzystających z opieki zdrowotnej powinny mobilizować organizatorów systemu do poszukiwań nowych rozwiązań, zwiększających efektywność (5).

Szpitale prowadzą działalność w sektorze, który nieustannie podlega przemianom wynikającym z wprowadzenia reform ochrony zdrowia, zmian finansowania, wprowadzenia nowych uregulowań prawnych (3). $\mathrm{Z}$ dniem 15 lipca 2016 r. weszła w życie ustawa z dnia 10 czerwca 2016 r. o zmianie ustawy o działalności leczniczej oraz niektórych innych ustaw (Dz. U. z 2016 r. poz. 960). Wśród nowych uregulowań ustawy znalazły się dodatkowe obowiązki kierownika samodzielnego publicznego zakładu opieki zdrowotnej związane z prowadzeniem gospodarki finansowej. $\mathrm{W}$ terminie do dnia 31 maja każdego roku kierownik samodzielnego publicznego zakładu opieki zdrowotnej sporządza i przekazuje podmiotowi tworzącemu raport o sytuacji ekonomiczno-finansowej samodzielnego publicznego zakładu opieki zdrowotnej. Raport jest przygotowywany na podstawie sprawozdania finansowego za poprzedni rok obrotowy. Zawiera analizę sytuacji ekonomiczno-finansowej, prognozę sytuacji ekonomiczno-finansowej na kolejne trzy lata obrotowe wraz z opisem przyjętych założeń oraz informację o istotnych zdarzeniach mających wpływ na sytuację ekonomiczno-finansową samodzielnego publicznego zakładu opieki zdrowotnej. Analizy i prognozy są opracowywane w oparciu o wskaźniki ekonomiczno-finansowe, które określone zostały w Rozporządzeniu Ministra Zdrowia z dnia 12 kwietnia 2017 r. w sprawie wskaźników ekonomiczno-finansowych niezbędnych do sporządzenia analizy oraz prognozy sytuacji ekonomiczno-finansowej samodzielnych publicznych zakładów opieki zdrowotnej (Dz. U. z 2017 r. poz. 832). Podstawowym założeniem wprowadzenia jednolitych wskaźników dla wszystkich podmiotów leczniczych jest zapewnienie przejrzystości i porównywalności wyników. Podmiot tworzący dokonuje oceny sytuacji ekonomiczno-finansowej samodzielnego publicznego zakładu opieki zdrowotnej na podstawie powyższego raportu. Powyższe ma służyć zwiększeniu efektywności bieżącej kontroli sytuacji finansowej podmiotów leczniczych i umożliwić szybsze reagowanie na zmiany. 
Additionally, there were changes in the Act of 27 September 2004 on health care services financed from public funds (Journal of Laws 2019, item 1373, as amended). On 1 October 2017, its amendment entered into force, implementing the System of Securing Basic Hospital Health Care Services (the securing system). The allocation of costs for the services provided on the basis of agreements made within this securing system is made in the form of a lump sum. The amount of the lump sum for the subsequent accounting period depends on the amount and structure of the services that were provided and reported by the health care provider in the previous accounting periods.

Financial liquidity is of great importance in ensuring operational continuity, as it determines health care entity's potential for development and its ability to operate under conditions of limited financial resources (6).

Financial liquidity is catalogued as one of the most prominent objectives in managing a health care entity. Maintaining appropriate level of financial liquidity determines the health care entity's statutory functioning. Deteriorating financial liquidity constraints the entity in terms of decision making and causes it to gradually lose its ability to adapt to the changing market conditions. Monitoring the health care entity's liquidity is the most important aspect of financial management (7).

The importance of financial liquidity can be defined as the health care entity's ability to meet its current liabilities - which depend on short-term liabilities and the level of current assets - in a timely manner (8).

The ability to meet current obligations manifests itself in such cash distribution that, on the one hand, does not cause any payment delays and on the other, does not lead to withholding an excessive amount of liquid assets (9). The timeliness in the payments of salaries and trade payables depends on the health care entity's financial liquidity.

The liquidity ratios are the most important ratios when it comes to the evaluation of the entity's current financial situation, as losing the ability to settle liabilities in a timely manner, quickly leads to serious disruptions in the entity's functioning and poses a threat to the business operations. When the level of the ratios drops, there is a risk that the entity will lose the ability to meet its liabilities in a timely manner. When the ratios are too high, it might indicate that the available working capital, such as inventory, receivables or cash, is managed inefficiently.

Maintaining liquidity in health care entities is vital in order to maintain continuity of the health care service provision and, at the same time, it is crucial to ensure health safety.
Dodatkowo nastapiły zmiany w ustawie z dnia 27 sierpnia 2004 r. o świadczeniach opieki zdrowotnej finansowanych ze środków publicznych (Dz. U. z 2019 r. poz. 1373 z późń. zm.), od 1 października 2017 r. weszła w życie jej nowelizacja wprowadzająca system podstawowego szpitalnego zabezpieczenia świadczeń opieki zdrowotnej (system zabezpieczenia). Rozliczanie kosztów świadczeń udzielanych na podstawie umów zawartych $\mathrm{w}$ ramach systemu zabezpieczenia odbywa się w formie ryczałtowej. Wysokość ryczałtu na kolejny okres rozliczeniowy zależy od liczby oraz struktury świadczeń udzielonych i sprawozdanych przez świadczeniodawcę w poprzednich okresach.

Płynność finansowa ma ogromne znaczenie dla zapewnienia możliwości kontynuacji działalności, gdyż charakteryzuje możliwości rozwojowe podmiotu leczniczego oraz funkcjonowania $\mathrm{w}$ warunkach ograniczonego zasilania finansowego (6).

Płynność finansowa należy do katalogu najważniejszych celów w zarządzaniu podmiotem leczniczym. Utrzymanie odpowiedniego poziomu płynności finansowej determinuje statutowe funkcjonowanie podmiotu leczniczego. Pogarszająca się płynność finansowa ogranicza podmiot leczniczy w podejmowaniu działań i sprawia, że stopniowo traci on zdolność do elastycznego dostosowania się do zmiennych warunków rynkowych. Monitorowanie płynności w podmiocie leczniczym jest najważniejszym obszarem zarządzania finansami (7).

Znaczenie płynności finansowej określa się, jako zdolność podmiotu leczniczego do terminowego regulowania zobowiązań bieżących, uwarunkowanych wielkością krótkoterminowego zadłużenia oraz poziomem aktywów obrotowych (8).

Zdolność do bieżącego regulowania zobowiązań przejawia się rozdysponowaniem środków pieniężnych w taki sposób, aby z jednej strony nie doprowadzić do jakichkolwiek opóźnień płatniczych, a z drugiej, aby nie dopuścić do utrzymywania się nadmiernej wielkości środków płynnych (9). Od płynności finansowej w podmiocie leczniczym zależy terminowość regulacji wynagrodzeń oraz zobowiązań z tytułu dostaw i usług.

Wskaźniki płynności finansowej to najważniejsze wskaźniki oceny bieżącej sytuacji finansowej, utrata możliwości terminowego regulowania zobowiązań prowadzi bowiem w krótkim czasie do poważnych zakłóceń w funkcjonowaniu jednostki oraz powstania zagrożenia dla prowadzenia działalności. Jeżeli poziom wskaźników obniża się, to występuje ryzyko utraty przez podmiot zdolności do terminowego regulowania zobowiązań. W przypadku, gdy wskaźniki są zbyt wysokie, może to świadczyć o nieefektywnym gospodarowaniu posiadanymi środkami obrotowymi, takimi jak zapasy, należności lub środki finansowe. 


\section{OBJECTIVE}

The objective of this study was to assess the financial liquidity of public hospitals, based on the example of public hospitals in Podlaskie Voivodeship in years 2013-2017.

The main objective was realised based on the following specific aims:

1. To analyse the level of revenues, expenses and financial performance.

2. To assess the financial liquidity with reference to current and quick ratio.

\section{MATERIALS AND METHODS}

Public hospitals, whose founding entity is the Podlaskie Voivodeship Self-government, were selected for the study. Hospitals' financial statement data from years 2013-2017 were used to assess the financial situation, paying special attention to financial liquidity.

In Podlaskie Voivodeship, there are 37 health care entities whose founding entities are: Podlaskie Voivodeship, counties, municipalities, the Ministry and the Medical University of Bialystok.

Podlaskie Voivodeship Self-government is the founding entity for 13 health care entities.

Among these, 9 entities provide stationary and round-the-clock health care services. These entities (at the date of 31/12/2016) had at their disposal 3,189 beds, which accounted for $53 \%$ of these resources in Podlaskie Voivodeship. In 2016, the number of hospitalisations in hospital treatment in this voivodeship equalled 274,551, whereas in hospitals, whose founding entity is Podlaskie Voivodeship, amounted to 98,310, which constitutes $36 \%$ of all hospitalisations.

The data for carrying out the analysis were obtained from the health care entities' financial statements from years 2013-2017. These were retrieved following the public information access procedure from the Podlaskie Voivodeship Marshal's Office in Bialystok. Revenues, expenses and financial performance data were rounded up to PLN 1.

The hospitals, in order to assess their financial situation, were divided into groups by their size expressed in number of beds. There were 2 groups (group 1 - number of beds up to 250 , group 2 - from 251 to 900 beds).

The characteristics of the studied health care entities are presented in Table 1.

Health care entities selected for the assessment play a significant role in securing basic hospital health care services which are provided in Podlaskie Voivodeship.

The assessment was made based on the data regarding the revenues, expenses and the financial performance of the case-study hospitals.
Utrzymanie płynności podmiotu leczniczego jest warunkiem koniecznym utrzymania ciągłości udzielania świadczeń opieki zdrowotnej, a tym samym kluczowym warunkiem zapewnienia bezpieczeństwa zdrowotnego.

\section{CEL PRACY}

Celem pracy jest ocena płynności finansowej szpitali publicznych, na przykładzie szpitali publicznych w województwie podlaskim w latach 2013-2017.

Cel główny zostanie zrealizowany w oparciu o następujące cele szczegółowe:

1. Analiza poziomu przychodów, kosztów oraz wyników finansowych.

2. Ocena płynności finansowej $\mathrm{z}$ uwzględnieniem wskaźnika płynności bieżącej oraz wskaźnika płynności szybkiej.

\section{MATERIAŁ I METODY}

Do badania wytypowano szpitale publiczne, dla których podmiotem tworzącym jest Samorząd Województwa Podlaskiego. Do oceny sytuacji finansowej, ze szczególnym uwzględnieniem płynności finansowej, wykorzystano informacje zawarte $\mathrm{w}$ sprawozdaniach finansowych szpitali w latach 2013-2017. W województwie podlaskim znajduje się 37 podmiotów leczniczych, których podmiotem tworzącym są: województwo podlaskie, powiaty, gminy, ministerstwo, Uniwersytet Medyczny w Białymstoku.

Samorząd Województwa Podlaskiego jest podmiotem tworzącym 13 podmiotów leczniczych.

Wśród nich stacjonarnych i całodobowych świadczeń zdrowotnych udziela 9 podmiotów leczniczych. Podmioty te (wg stanu na dzień 31.12.2016 r.) dysponowały 3189 łóźkami, co stanowiło 53\% tych zasobów w województwie podlaskim. Liczba hospitalizacji w leczeniu szpitalnym w 2016 r. wyniosła w województwie 274 551, a w szpitalach, dla których podmiotem tworzącym jest Województwo Podlaskie - 98 310, tj. 36\% wszystkich hospitalizacji.

Informacje do wykonania analizy uzyskano ze sprawozdań finansowych podmiotów leczniczych z lat 2013-2017, które uzyskano przy wykorzystaniu procedury dostępu do informacji publicznej od Urzędu Marszałkowskiego Województwa Podlaskiego w Białymstoku. Informacje w zakresie przychodów, kosztów i wyników finansowych zostały zaokrąglone do $1 \mathrm{zł}$.

Przy ocenie sytuacji finansowej szpitali dokonano ich podziału w zależności od wielkości szpitala mierzonej liczbą łóżek. Szpitale zostały podzielone na 2 grupy (grupa 1 - liczba łóżek do 250, grupa 2 - od 251 do 900).

W tabeli I przedstawiono charakterystykę badanych podmiotów leczniczych. 
Table I. Characteristics of the studied health care entities

Tabela I. Charakterystyka badanych podmiotów leczniczych

\begin{tabular}{|l|l|}
\hline $\begin{array}{l}\text { Group } 1 \\
\text { (number of beds up to 250) }\end{array}$ & $\begin{array}{l}4 \text { hospitals were classified to this group; these included hospitals with } 30 \text { to } 192 \text { beds; } \\
\text { the hospitals were of a single speciality nature, a hospital aimed at cancer treatment, } \\
\text { rehabilitation and palliative/hospice care which also provided health care services for } \\
\text { alcohol and other psychoactive substances addicts stood out from the rest }\end{array}$ \\
\hline $\begin{array}{l}\text { Group } 2 \\
\text { (number of beds from 251 to 900) }\end{array}$ & $\begin{array}{l}4 \text { hospitals were classified to this group; these included hospitals with } 282 \text { to } 892 \\
\text { beds; in this study group there were 3 multi-speciality hospitals and } 2 \text { hospitals } \\
\text { providing patients with mental disorders with a comprehensive care. }\end{array}$ \\
\hline
\end{tabular}

Source: Own elaboration.

Źródto: opracowanie własne.

The current ratio, which measures the entity's ability to pay its short-term obligations, and the quick ratio, that measures the entity's ability to meet its short-term obligations with its most liquid assets, were calculated in order to assess the hospitals' financial liquidity. The current and the quick ratio formulas are presented in Table 2.

The optimal values for the current and quick ratios are presented in Table 3 with accordance to the Regulation of the Minister of Health of 12 April 2017 on economic and financial ratios necessary for the analysis and forecast of independent public health care centres' economic and financial situation (Journal of Laws 2017, item 832)
Wybrane do oceny podmioty lecznicze odgrywają znaczącą rolę w zabezpieczeniu świadczeń zdrowotnych udzielanych w województwie podlaskim.

Do oceny wykorzystano informacje o przychodach, kosztach i wyniku finansowym badanych szpitali. Do oceny płynności finansowej szpitali obliczono wskaźnik bieżącej płynności, który określa zdolność podmiotu do terminowego regulowania zaciągniętych zobowiązań krótkoterminowych oraz wskaźnik szybkiej płynności, który określa zdolność podmiotu do spłacania zobowiązań krótkoterminowych najbardziej płynnymi aktywami. W tabeli II zaprezentowano formuły obliczenia wskaźnika bieżącej płynności oraz wskaźnika szybkiej płynności.

Table II. Current and quick ratio formula

Tabela II. Formuła obliczenia wskaźnika bieżącej płynności oraz szybkiej płynności

\begin{tabular}{|c|c|}
\hline Ratio & Formula \\
\hline Current ratio & $\begin{array}{l}\text { current assets - short-term trade receivables due in more than } 12 \text { months - short-term prepaid expenses } \\
\text { current liabilities - trade payables due in more than } 12 \text { months + inventory for current liabilities }\end{array}$ \\
\hline Quick ratio & $\begin{array}{l}\text { current assets - short-term trade receivables due in more than } 12 \text { months - sort-term prepaid expenses - } \\
\text { inventory current liabilities - trade payables due in more than } 12 \text { months + inventory for current liabilities }\end{array}$ \\
\hline \multicolumn{2}{|c|}{$\begin{array}{l}\text { Source: Own elaboration based on the Regulation of the Minister of Health of } 12 \text { April } 2017 \text { on economic and financial ratios necessary } \\
\text { for the analysis and forecast of independent public health care centres'economic and financial situation (Journal of Laws 2017, item 832). } \\
\text { Źródto: opracowanie własne na podstawie Rozporzadzenia Ministra Zdrowia z dnia } 12 \text { kwietnia } 2017 \text { r. w sprawie wskaźników ekonomiczno- } \\
\text { finansowych niezbędnych do sporzadzania analizy oraz prognozy sytuacji ekonomiczno-finansowej samodzielnych publicznych zaktadów } \\
\text { opieki zdrowotnej (Dz. U. z } 2017 \text { r. poz. 832). }\end{array}$} \\
\hline *in hospital group & $\begin{array}{l}\text { d 2, when calculating the current and quick ratios, there were no short-term trade receivables due in more than } 12 \text { months or trade } \\
\text { lan } 12 \text { months. }\end{array}$ \\
\hline
\end{tabular}

Table III. Optimal values of the current and quick ratio

Tabela III. Wartości optymalne wskaźników bieżącej płynności oraz szybkiej płynności

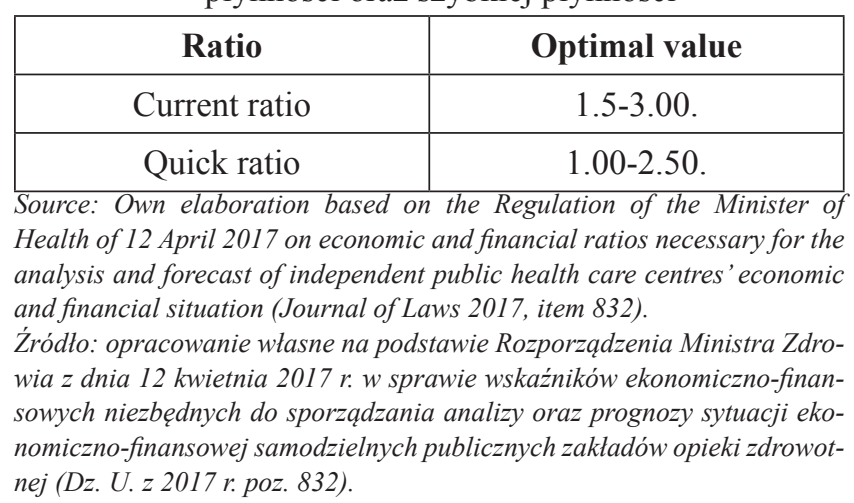

Zgodnie z Rozporządzeniem Ministra Zdrowia z dnia 12 kwietnia 2017 r. w sprawie wskaźników ekonomiczno-finansowych niezbędnych do sporządzenia analizy oraz prognozy sytuacji ekonomiczno-finansowej samodzielnych publicznych zakładów opieki zdrowotnej (Dz. U. z 2017 r. poz. 832) w tabeli III zaprezentowano wartości optymalne wskaźnika bieżącej płynności oraz wskaźnika szybkiej płynności. 


\section{RESULTS}

In years 2013-2017, a steady increase was recorded in the revenues and expenses of the health care entities whose founding entity is Podlaskie Voivodeship. The increase is presented in Table 4.

\section{WYNIKI}

W latach 2013-2017 obserwowano systematyczny wzrost przychodów i kosztów podmiotów leczniczych, dla których podmiotem tworzącym jest Województwo Podlaskie, co przedstawiono w tabeli IV.

Table IV. Revenues, expenses, and financial performance of hospitals whose founding entity is Podlaskie Voivodeship in years 2013-2017

Tabela IV. Przychody, koszty oraz wynik finansowy szpitali, dla których podmiotem tworzącym jest Województwo Podlaskie w latach 2013-2017

\begin{tabular}{|c|c|c|c|c|c|}
\hline & 2013 & 2014 & 2015 & 2016 & 2017 \\
\hline Revenues, including & $485,071,860$ & $509,532,712$ & $526,840,599$ & $561,629,983$ & $607,715,615$ \\
\hline $\begin{array}{l}\text { Revenues } \\
(\text { number of beds }>250)\end{array}$ & $380,835,343$ & $390,627,297$ & $406,293,438$ & $431,532,431$ & $465,837,673$ \\
\hline $\begin{array}{l}\text { Revenues } \\
\text { (number of beds }<250 \text { ) }\end{array}$ & $104,236,517$ & $118,905,415$ & $120,547,161$ & $130,097,552$ & $141,877,942$ \\
\hline Expenses, including & $481,163,754$ & $500,894,873$ & $523,587,035$ & $552,175,368$ & 598,342,507 \\
\hline $\begin{array}{l}\text { Expenses } \\
(\text { number of beds }>250)\end{array}$ & $378,529,918$ & $385,564,177$ & $400,179,657$ & $423,406,458$ & $458,964,951$ \\
\hline $\begin{array}{l}\text { Expenses } \\
(\text { number of beds }<250)\end{array}$ & $102,633,836$ & $115,330,695$ & $123,407,378$ & $128,768,911$ & $139,377,555$ \\
\hline $\begin{array}{l}\text { Financial performance, } \\
\text { including }\end{array}$ & $3,908,106$ & $8,637,839$ & $3,253,564$ & $9,454,614$ & $9,373,108$ \\
\hline $\begin{array}{l}\text { Financial performance } \\
(\text { number of beds }>250 \text { ) }\end{array}$ & $2,305,425$ & $5,063,119$ & $6,113,781$ & $8,125,973$ & $6,872,721$ \\
\hline $\begin{array}{l}\text { Financial performance } \\
(\text { number of beds }<250 \text { ) }\end{array}$ & $1,602,681$ & $3,574,720$ & $-2,860,217$ & $1,328,641$ & $2,500,387$ \\
\hline
\end{tabular}

In 2013, the revenues totalled PLN 485,071,860, whereas in 2017 , they were $25 \%$ higher and amounted to PLN 485,071,860. In the same period, the expenses increased by $24 \%$ and in 2017 equalled PLN $598,342,507$.

In the study period, the changes in the revenues and expenses of the hospitals, depending on the number of beds, were diversified and bigger in smaller hospitals. In years 2013-2017, the total revenue of hospitals with more than 250 beds increased by $22 \%$, whereas the revenue of hospitals with less than 250 beds increased by $36 \%$. The total expenses of hospitals with more than 250 beds increased by $21 \%$ and in hospitals with less than 250 beds, they increased by $35 \%$. The general financial performance of these entities improved significantly. In 2017, it amounted to PLN 9,373,108 and was $140 \%$ bigger than in 2013 (PLN 3,908,106). A significant improvement was observed in the financial performance of hospitals with more than 250 beds. In the study period, in years 2013-2017, the financial performance increased by PLN 4,567,296, that is by $198 \%$, whereas in hospitals with less than 250 beds it increased by PLN 897,706, that is by $56 \%$.
W 2013 r. przychody ogółem wyniosły 485071860 zł, a w 2017 r. były o 25\% wyższe i wyniosły 607715615 zł. Koszty ogółem w analogicznym okresie wzrosły o 24\% i wyniosły w 2017 r. 598342507 zł.

Zmiany przychodów i kosztów w analizowanym okresie w szpitalach, w zależności od liczby łóżek, były zróżnicowane i większe w szpitalach mniejszych. W latach 2013-2017 przychody ogółem w szpitalach o liczbie łóżek powyżej 250 wzrosły o $22 \%$, natomiast w szpitalach o liczbie łóżek poniżej 250 wzrosły o $36 \%$. Koszty ogółem w szpitalach o liczbie łóżek powyżej 250 wzrosły o $21 \%$, a w szpitalach poniżej 250 łóżek wzrosły o $35 \%$. Wynik finansowy ogółem tych podmiotów uległ znacznej poprawie. W $2017 \mathrm{r}$. wyniósł 9373108 zł i był o 140\% większy niż w roku 2013 r. (3 908106 zł). Obserwuje się, iż wynik finansowy szpitali o liczbie łóżek powyżej 250 uległ znaczącej poprawie. W badanym okresie lat 2013-2017 wynik finansowy zwiększył się o kwotę 4567296 zł, tj. o $198 \%$, natomiast wynik finansowy szpitali o liczbie łóżek poniżej 250 zwiększył się o kwotę 897706 zł, tj. o $56 \%$. 
Current ratio, which reflects basic relations that should exist between current assets and the amount of current liabilities, is presented in Table 5. In the assessment period, the current ratio in the hospitals was average, exceeding the optimal value. This means that the current assets employed in hospitals were bigger than the amount of current liabilities.
W tabeli V zaprezentowano wskaźnik bieżącej płynności, który odzwierciedla podstawowe relacje, jakie powinny zachodzić między majątkiem obrotowym a wielkością zobowiązań bieżących. Szpitale wykazywały w ocenianym okresie wartości średnie wskaźnika bieżącej płynności, powyżej wartości optymalnych. Oznacza to, że majątek obrotowy zaangażowany w szpitalach jest większy niż suma zobowiązań bieżących.

Table V. Current ratio in hospitals with $>250$ beds and $<250$ beds whose founding entity is Podlaskie Voivodeship in years 2013-2017 Tabela V. Wskaźnik bieżącej płynności w szpitalach, dla których podmiotem tworzącym jest Województwo Podlaskie w latach 2013-2017 z podziałem na szpitale $>250$ łóżek oraz $<250$ łóżek

\begin{tabular}{|c|c|c|c|c|c|}
\hline \multirow{2}{*}{ Specification } & \multicolumn{5}{|c|}{ Year } \\
\hline & 2013 & 2014 & 2015 & 2016 & 2017 \\
\hline & \multicolumn{5}{|c|}{ Current ratio } \\
\hline Min. & 0.41 & 0.47 & 0.45 & 0.41 & 0.34 \\
\hline Max. & 30.25 & 7.96 & 17.00 & 22.73 & 44.13 \\
\hline Arithmetic mean & 5.89 & 3.56 & 4.84 & 5.40 & 7.41 \\
\hline Median & 3.68 & 4.60 & 2.03 & 3.18 & 2.46 \\
\hline Standard deviation & 9.44 & 2.92 & 6.21 & 7.13 & 14.00 \\
\hline \multirow[t]{2}{*}{ Coefficient of variation } & 1.60 & 0.82 & 1.28 & 1.32 & 1.89 \\
\hline & \multicolumn{5}{|c|}{ hospitals $>250$ beds } \\
\hline Min. & 0.41 & 0.47 & 0.45 & 0.41 & 0.34 \\
\hline Max. & 3.68 & 4.60 & 3.67 & 8.42 & 2.46 \\
\hline Arithmetic mean & 1.25 & 1.42 & 1.25 & 2.31 & 1.06 \\
\hline Median & 0.74 & 0.60 & 0.64 & 0.69 & 0.65 \\
\hline Standard deviation & 1.37 & 1.78 & 1.37 & 3.44 & 0.90 \\
\hline \multirow[t]{2}{*}{ Coefficient of variation } & 1.10 & 1.25 & 1.10 & 1.49 & 0.84 \\
\hline & \multicolumn{5}{|c|}{ hospitals $<250$ beds } \\
\hline Min. & 4.23 & 5.40 & 2.03 & 3.18 & 4.70 \\
\hline Max. & 30.25 & 7.96 & 17.00 & 22.73 & 44.13 \\
\hline Arithmetic mean & 11.70 & 6.23 & 9.34 & 9.28 & 15.36 \\
\hline Median & 6.17 & 5.77 & 9.16 & 5.60 & 6.30 \\
\hline Standard deviation & 12.42 & 1.17 & 7.20 & 9.15 & 19.24 \\
\hline Coefficient of variation & 1.06 & 0.19 & 0.77 & 0.99 & 1.25 \\
\hline
\end{tabular}

Source: Own elaboration based on financial statements of hospitals whose founding entity is Podlaskie Voivodeship.

Źródło: opracowanie własne na podstawie sprawozdań finansowych Szpitali, dla których podmiotem tworzacym jest Województwo Podlaskie.

In the first hospital group (number of beds $>250$ ), the current ratio was below the optimal value (except for 2016), which may indicate the lack of the hospitals' ability to meet its repayment obligations in an immediate manner. In the second hospital group (number of beds $<250$ ), current ratios were above the optimal value. If creditors requested these hospitals to repay their obligations immediately, the hospitals would be able to pay. The minimum current ratio observed was 0.34 , whereas the maximum equalled 44.13 .

Quick ratio, that measures the extent to which short-term obligations can be met with highly liquid assets, was calculated in Table 6 . The quick ratio was very similar to the current ratio, which indicates low hospitals' inventory levels.
Pierwsza grupa szpitali (liczba łóżek>250) osiągnęła wartości wskaźnika bieżącej płynności poniżej wartości optymalnych (za wyjątkiem 2016 r.), co może świadczyć o braku zdolności szpitali do natychmiastowej splaty zobowiązań. Druga grupa szpitali (liczba łóżek<250) charakteryzowała się wartościami wskaźników bieżącej płynności finansowej powyżej wartości optymalnej. W przypadku, gdy wierzyciele zwróciliby się do powyższych szpitali o natychmiastową spłatę należności, szpitale byłyby w stanie spłacić te zobowiązania. Minimalna zaobserwowana wartość wskaźnika bieżącej płynności wynosi 0,34 a maksymalna to 44,13 .

W tabeli VI obliczono wskaźnik szybkiej płynności, który służy do oceny stopnia pokrycia zobowiązań krótkoterminowych aktywami o dużym stopniu płynności. Wskaźnik płynności szybkiej przyjmuje bardzo zbliżone wartości do wskaźnika płynności bieżącej, co świadczy o niskim poziomie zapasów w szpitalach. 
Table VI. Quick ratio in hospitals with $>250$ beds and $<250$ beds whose founding entity is Podlaskie Voivodeship in years 2013-2017

\begin{tabular}{|c|c|c|c|c|c|}
\hline \multirow{2}{*}{ Specification } & \multicolumn{5}{|c|}{ Year } \\
\hline & 2013 & 2014 & 2015 & 2016 & 2017 \\
\hline & \multicolumn{5}{|c|}{ Quick ratio } \\
\hline Min. & 0.38 & 0.43 & 0.42 & 0.37 & 0.30 \\
\hline Max. & 30.25 & 7.90 & 16.83 & 22.57 & 43.91 \\
\hline Arithmetic mean & 5.75 & 3.40 & 4.72 & 5.27 & 7.27 \\
\hline Median & 3.46 & 4.35 & 1.71 & 2.73 & 2.22 \\
\hline Standard deviation & 9.47 & 2.85 & 6.19 & 7.11 & 13.96 \\
\hline \multirow[t]{2}{*}{ Coefficient of variation } & 1.65 & 0.84 & 1.31 & 1.35 & 1.92 \\
\hline & \multicolumn{5}{|c|}{ hospitals $>250$ beds } \\
\hline Min. & 0.38 & 0.43 & 0.42 & 0.37 & 0.30 \\
\hline Max. & 3.46 & 4.35 & 3.49 & 8.26 & 2.22 \\
\hline Arithmetic mean & 1.17 & 1.33 & 1.16 & 2.22 & 0.97 \\
\hline Median & 0.68 & 0.57 & 0.57 & 0.62 & 0.58 \\
\hline Standard deviation & 1.29 & 1.70 & 1.31 & 3.40 & 0.81 \\
\hline \multirow[t]{2}{*}{ Coefficient of variation } & 1.11 & 1.28 & 1.13 & 1.53 & 0.84 \\
\hline & \multicolumn{5}{|c|}{ hospitals $<250$ beds } \\
\hline Min. & 3.74 & 4.93 & 1.71 & 2.73 & 4.23 \\
\hline Max. & 30.25 & 7.90 & 16.83 & 22.57 & 43.91 \\
\hline Arithmetic mean & 11.49 & 5.98 & 9.18 & 9.08 & 15.15 \\
\hline Median & 5.98 & 5.55 & 9.08 & 5.52 & 6.22 \\
\hline Standard deviation & 12.56 & 1.32 & 7.23 & 9.19 & 19.24 \\
\hline Coefficient of variation & 1.09 & 0.22 & 0.79 & 1.01 & 1.27 \\
\hline
\end{tabular}

Source: Own elaboration based on financial statements of the hospitalswhose founding entity is Podlaskie Voivodeship.

Źródto: opracowanie własne na podstawie sprawozdań finansowych Szpitali, dla których podmiotem tworzacym jest Województwo Podlaskie.

In hospitals with less than 250 beds, the mean ratio was high, whereas in hospitals with more than 250 beds, the mean quick ratio was optimal, which means that the hospitals would be able to meet their current liabilities, in case these became payable on demand; e.g. by liquidating their current assets without having to convert their fixed assets into cash. The minimum quick ratio observed was 0.30 , whereas the maximum equalled 43.91 .

\section{DISCUSSION}

A hospital is a health care institution that fulfils the following principal objectives: the readiness to admit and treat patients, including the readiness to provide the patients with medical care accessibility, and the maintenance of financial liquidity. Although the hospital's activities are not aimed at maximising profits, meeting its financial objectives means that at least the financial liquidity is being pursued. The data, that is indispensable for the management's decision making in this context, were obtained from the financial analysis. The aim of financial analysis is to describe the financial situation with the use of financial ratios, such as those measuring the entity's profitability, liquidity, efficiency and debt (10).
Szpitale o liczbie łóżek poniżej 250 odnotowały wysokie średnie wartości wskaźnika, a szpitale o liczbie łóżek powyżej 250 odnotowały optymalne średnie wartości wskaźnika szybkiej płynności, co świadczy o możliwości spłaty zobowiązań bieżących w przypadku, gdy stałyby się natychmiast wymagalne, np. poprzez upłynnienie majątku obrotowego, bez konieczności upłynniania części aktywów trwałych. Minimalna zaobserwowana wartość wskaźnika szybkiej płynności wynosi 0,30 , a maksymalna to 43,91 .

\section{DYSKUSJA}

Szpital jest zakładem opieki zdrowotnej realizującym następujące zasadnicze cele: gotowość przyjęcia i leczenia pacjenta, w tym gotowość zapewnienia mu dostępności opieki medycznej oraz utrzymanie płynności finansowej. Mimo, iż podstawowa działalność szpitala nie jest nastawiona na maksymalizację zysku, to realizacja celu ekonomicznego oznacza dążenie przynajmniej do utrzymania płynności finansowej. Niezbędnych informacji do podejmowania decyzji zarządczych w tym zakresie dostarcza analiza finansowa. Zadaniem analizy finansowej jest opis sytuacji finansowej z perspektywy wskaźników ekonomicznych takich jak zyskowność, płynność, efektywność oraz zadłużenie podmiotu (10). 
Hospitals' financial situation is an issue of the management, founding entities, decision-makers and media's interest. More and more frequently, hospitals are perceived as enterprises that are required to function according to the market economy, without taking into consideration health care sector specific features (11). Currently, many health care entities are not able to meet their current obligations with suppliers. The hospitals' obligations are increasing because of the increasing costs which derive from, for example, the payers' demands on medical care standards. Additionally, in the health care sector, an increase in remuneration is being observed, which includes, among others, an increase in the basic salary of staff performing medical professions employed in medical entities - the Act of 8 June 2017 on the method for determining the lowest basic salary of workers performing medical professions employed in health care entities (Journal of Laws 2019, item 1471, consolidated text); the minimum wage - the Act of 10 October 2002 on the minimum wage (Journal of Laws 2018, item 2177, consolidated text); and in the remuneration of resident doctors - the Regulation of the Minister of Health of 6 September 2018 on the amount of basic monthly remuneration for doctors and dentists specialising during their residency (Journal of Laws 2018, item 1737).

It should be noted that the hospitals' financial situation may originate from external factors and arise from, for example, over- or understatement of the medial procedures' value. It can also be related to mismanagement, i.e. the lack of costs' control, inefficiency in maximising the revenues and the tendency to indebtedness (12).

The lack of balance between the expenses and the revenues obtained is the cause of the hospitals' unstable financial situation, whereas the uncontrolled level of indebtedness can lead to the financial liquidity's loss.

The health care entity's management are required to maintain the financial liquidity at optimal level. If a health care entity reaches low liquidity level, it means that it will face problems with meeting its obligations towards its suppliers in a timely manner. Such situation may lead to the deterioration of the conditions of collaboration with the contractors, reductions of payment periods or the necessity to seek a deferral of the payment deadlines for the entity's liabilities.

When working capital is significantly bigger than liabilities, excess liquidity occurs. This is an undesirable situation, as it leads to a decrease in the efficiency and use of the working capital, which decreases the health care entity's profitability. Public hospitals can adopt a conservative method, i.e. financial resources that the hospitals collected can be invested in new medical equipment. However, there is the uncertainty related to the fact that hospitals often have no guarantee when it
Sytuacja finansowa szpitali stanowi przedmiot zainteresowania zarządzających podmiotów tworzących, decydentów oraz mediów. Szpitale coraz częściej są traktowane jak przedsiębiorstwa, od których wymaga się funkcjonowania na zasadach gospodarki rynkowej, nie uwzględniając przy tym specyfiki rynku usług zdrowotnych (11). Obecnie wiele podmiotów leczniczych nie jest w stanie na bieżąco regulować swoich zobowiązań u dostawców. Zobowiązania szpitali wzrastają, ponieważ wzrastają koszty funkcjonowania, wynikające np. z wymagań płatników dotyczących standardów opieki medycznej. Ponadto obserwowany jest wzrost wynagrodzeń w ochronie zdrowia m.in.: wynagrodzenia zasadniczego pracowników wykonujących zawody medyczne zatrudnionych w podmiotach leczniczych ustawa $\mathrm{z}$ dnia 8 czerwca 2017 r. o sposobie ustalania najniższego wynagrodzenia zasadniczego pracowników wykonujących zawody medyczne zatrudnionych w podmiotach leczniczych (Dz. U. z 2019 r., poz. 1471 t.j.), minimalnego wynagrodzenia - ustawa $z$ dnia 10 października 2002 r. o minimalnym wynagrodzeniu za pracę (Dz. U. z 2018 r., poz. 2177 t.j.) oraz wzrost wynagrodzeń lekarzy rezydentów - rozporządzenie Ministra Zdrowia z dnia 6 września 2018 r. w sprawie wysokości zasadniczego wynagrodzenia miesięcznego lekarzy i lekarzy dentystów odbywających specjalizacje w ramach rezydentury (Dz. U. z 2018 r., poz. 1737).

Należałoby zwrócić uwagę, że sytuacja finansowa szpitali może mieć swoje źródła w otoczeniu zewnętrznym i wynikać np. $z$ niedoszacowania lub przeszacowania wyceny procedur medycznych. Może być też związana z niegospodarnością kadry zarządzającej t.j.: niekontrolowanie kosztów, brak efektywności zwiększania przychodów oraz skłonność do zadłużania się (12).

Brak równowagi pomiędzy kosztami a uzyskiwanymi przychodami jest przyczyną niestabilnej sytuacji finansowej szpitali, a niekontrolowany wzrost zadłużenia może doprowadzić do utraty płynności finansowej.

Zarządzający podmiotem leczniczym są zobowiązani do utrzymania płynności finansowej na optymalnym poziomie. W przypadku, gdy podmiot leczniczy osiągnie niski poziom płynności, oznaczać to będzie, iż pojawią się problemy $z$ terminowym regulowaniem zobowiązań wobec dostawców. Powyższa sytuacja może doprowadzić do pogorszenia warunków współpracy z kontrahentami, skracania terminów płatności, bądź konieczności ubiegania się o odroczenie terminów spłaty zobowiązań.

W przypadku, gdy środków obrotowych jest znacznie więcej niż zobowiązań, pojawia się nadpłynność, która jest sytuacją niepożądaną, bo prowadzi do obniżenia efektywności środków obrotowych oraz ich wykorzystania, co zmniejszy rentowność podmiotu leczniczego. Szpitale publiczne mogą stosować meto- 
comes to funding new health care services by the public payer. Moreover, the problem of selecting qualified medial staff occurs more and more frequently.

The analysis and knowledge of the health care entity's financial situation is an important aspect from the management and the founding entity's perspective. An example of such analysis is Łagowski's work Analiza finansowa kluczowych podmiotów leczniczych $w$ województwie dolnoślaskim [Financial analysis of the key health care entities in Lower Silesia] (13).

In order to maintain hospitals' financial liquidity at optimal level, a number of actions are undertaken. They include both actions that take place at the system level, as well as those performed directly by the health care entities. Diversification of the activity's financing sources may enable the financial liquidity improvement. Currently, hospitals are forced to seek alternative financing sources, e.g. grants from the European Union, and to systematically undertake actions that are aimed at increasing their operating efficiency, including their economic efficiency. Negotiations with the payer and the contractors may be a good example of such actions, as well as the examination of new/alternative financing sources, such as private funds, foundations and local governments.

In case of loss of the financial liquidity, hospitals are obliged to take corrective action. Financial restructuring of a hospital is a matter that belongs to the leading area of restructuring. The main objective of undertaking financial restructuring is to regain financial liquidity and maintain an optimal balance between the debt and own funds. One of the first steps taken in the stage of restructuring is to reduce the hospital debt by deferring payment deadlines; that is to change the liabilities that are due to be repaid into long term liabilities, arrange for debt repayment in instalments, reduce costs and expenses and to improve the financial structure and management (3).

External factors, such as those related to the legislative solutions used, affect the hospitals' financial situation. In Poland, the new solution is the implementation of the System of Securing Basic Hospital Health Care Services (the securing system). It is supposed to make the organisation of the health care service provision by hospitals and hospital outpatient clinics more efficient and improve the patients' access to specialist treatment in hospitals. The aim of creating the securing system is to make hospitals' management more flexible and optimise medical cost structure, as well as to guarantee the continuity and stability in the hospitals' financing, which gives the hospitals an opportunity to maintain their financial liquidity and provide their patients with health security. The period analysed in this study, immediately precedes the implementation of the securing system and, at this stage, the assessment of the results of implementing such solution is not possible. Only once the dę zachowawczą, tzn. zgromadzone środki finansowe przez szpital publiczny mogłyby być zainwestowane w nowy sprzęt medyczny, ale pojawia się niepewność związana z tym, że szpital często nie ma gwarancji finansowania nowych świadczeń zdrowotnych przez publicznego płatnika, a ponadto coraz częściej pojawia się problem z doborem wykwalifikowanej kadry medycznej.

Analiza i poznanie sytuacji finansowej podmiotu leczniczego jest istotną kwestią z punktu widzenia kadry zarządzającej oraz podmiotu tworzącego. Przykładem takiej analizy jest opracowanie P. Łagowskiego „Analiza finansowa kluczowych podmiotów leczniczych w województwie dolnoślaskim" (13).

W celu utrzymania optymalnego poziomu płynności finansowej szpitali, podejmowane są różne działania zarówno systemowe, jak i bezpośrednio przez podmioty lecznicze. Poprawę płynności finansowej może umożliwiać dywersyfikacja źródeł finansowania działalności. Aktualnie szpitale zmuszone są do poszukiwania alternatywnych źródeł finansowania np. dotacji ze środków Unii Europejskiej oraz do systematycznego podejmowania działań, które mają na celu zwiększenie efektywności działania, w tym efektywności ekonomicznej. Dobrym przykładem mogą być negocjacje z płatnikiem lub kontrahentami oraz przeanalizowanie nowych/alternatywnych źródeł finansowania np. środki prywatne, fundacje, samorządy.

W przypadku utraty płynności finansowej szpitale zobowiązane są do podjęcia działań naprawczych. Do wiodącego obszaru restrukturyzacji należy sfera restrukturyzacji finansowej szpitala. Głównym celem podejmowania restrukturyzacji finansowej jest odzyskanie płynności finansowej oraz utrzymanie optymalnej relacji pomiędzy zadłużeniem a środkami własnymi. Jednym z pierwszych działań na etapie restrukturyzacji jest oddłużanie szpitala poprzez odroczenie terminów spłaty długów, czyli zamianę zobowiązań wymagalnych na zobowiązania długoterminowe, rozłożenie spłaty zadłużenia na raty, redukcja kosztów i wydatków oraz poprawa struktury finansowej i zarządzania finansami (3).

$\mathrm{Na}$ sytuację finansową szpitali mają wpływ czynniki zewnętrzne, związane np. ze stosowanymi rozwiązaniami legislacyjnymi. Nowym rozwiązaniem w Polsce jest wprowadzenie systemu podstawowego szpitalnego zabezpieczenia świadczeń opieki zdrowotnej (system zabezpieczenia), który ma usprawnić organizację udzielania świadczeń opieki zdrowotnej przez szpitale i przychodnie przyszpitalne oraz poprawić dostęp pacjentów do leczenia specjalistycznego w szpitalach. Celem utworzenia systemu zabezpieczenia jest uelastycznienie zarządzania szpitalem oraz optymalizacja struktury kosztów leczenia, w tym zagwarantowanie ciągłości i stabilności finansowania szpitali, co 
situation is stable, i.e. once the new legal solutions are fully implemented, it will be possible to assess - paying special attention to the financial liquidity - the impact that the introduced changes have on the health care entities' financial situation.

In the literature, there are many valuable works on this topic. Among others, it is worth mentioning the BFF Banking Group's report Finansowanie ochrony zdrowia a jakość systemu dla pacjenta. Polska na tle wybranych krajów europejskich [Health care funding and the system's quality for the patient. Poland compared to other European countries] (14).

\section{CONCLUSIONS}

Financial liquidity management should be the management's priority when managing hospital's finances. The management's actions should be multidirectional and based on information about the financial situation of the hospital and the hospital's ratio analysis, which is vital for the management's decision making.

The carried out analysis showed that the financial situation in the case-study hospitals was good. It was observed that the revenues were commensurate with the expenses, whereas the financial performance was positive.

In the study period, hospitals were able to meet their financial obligations, which corroborates efficient financial liquidity management.

Hospitals with large bed resources should intensify their actions to maintain and improve their financial liquidity and their ability to repay their obligations, as they are at risk of losing such ability.

Smaller hospitals, which are characterised by excess liquidity, should change the rules that govern their financial management and optimise their liquidity ratios, which is what will enable a more efficient use of their financial resources.

\section{REFERENCES}

1. Hass-Symotiuk M. (red). Szpital jako podmiot oceny przez różnych interesariuszy. System pomiaru i oceny dokonań szpitala. Wolters Kluwer Polska Sp. z o.o., Warszawa 2011, 11-20.

2. http://www.nfz.gov.pl/bip/finanse-nfz/

3. Karkowski T. Szpital jako przedmiot działań restrukturyzacyjnych i jego otoczenie, Restrukturyzacja jako narzędzie mające na celu poprawę funkcjonowania szpitala. Restrukturyzacja Szpitali. Choiński A. Warszawa: Wolters Kluwer Polska 2012: 25-38, 82-109.

4. Raulinajtys-Grzybek M. Zmiany na rynku opieki zdrowotnej i ich wpływ na funkcjonowanie podmiotów leczniczych. Zarządzanie kosztami podmiotów leczniczych: rola i zadania pielęgniarek. Wolters Kluwer Polska Sp. z o.o., Warszawa: Wolters Kluwer Polska 2013: 13-19. daje szansę na utrzymanie płynności finansowej szpitali i zapewnienie bezpieczeństwa zdrowotnego pacjentów. Okres poddany analizie w badaniu bezpośrednio poprzedza wprowadzenie systemu zabezpieczenia i nie jest możliwa na tym etapie ocena skutków wprowadzenia tego rozwiązania. Ocenę wpływu wprowadzonych zmian na sytuację finansową podmiotów leczniczych, ze szczególnym uwzględnieniem płynności finansowej będzie można wykonać po ustabilizowaniu się sytuacji tj. po pełnym wdrożeniu nowych rozwiązań prawnych.

$\mathrm{Na}$ dany temat $\mathrm{w}$ literaturze przedmiotu jest wiele cennych opracowań między innymi warto jest wskazać raport BFF Banking Group - "Finansowanie ochrony zdrowia a jakość systemu dla pacjenta. Polska na tle wybranych krajów europejskich." (14).

\section{WNIOSKI}

Zarządzanie płynnością finansową w szpitalu powinno być priorytetowym działaniem kadry zarządzającej w zakresie zarządzania finansami. Działania te powinny być wielokierunkowe i oparte na informacji o sytuacji finansowej oraz analizie wskaźnikowej szpitala, niezbędnej do podejmowania decyzji zarządczych.

Przeprowadzona analiza wykazała, że w badanych szpitalach publicznych sytuacja finansowa była dobra. Obserwowano współmierność przychodów i kosztów, a wyniki finansowe były dodatnie.

Szpitale posiadały zdolność regulowania zobowiązań finansowych w analizowanym okresie, co potwierdza efektywne zarządzanie płynnością finansową.

Szpitale o dużych zasobach łóżkowych powinny zintensyfikować swoje działania w celu utrzymania i poprawy płynności finansowej oraz spłaty zobowiązań, ponieważ istnieje realne ryzyko utraty tej możliwości.

Mniejsze szpitale, które charakteryzują się nadpłynnością finansową, powinny zmienić zasady gospodarowania środkami finansowymi i zoptymalizować wartości wskaźników płynności finansowej, co umożliwi efektywniejsze wykorzystanie środków finansowych.

5. Felińczak A. i Fal A. M. (red.). Podstawy zdrowia publicznego. Zdrowie publiczne: podręcznik akademicki. Uniwersytet Medyczny Wrocław, Warszawa 2010, 9.

6. Gołaś Z, Bieniasz A Czerwińska-Keyzer D. Stopień pokrycia zapotrzebowania na kapitał pracujący kapitałem stałym netto jako miara płynności finansowej. Zeszyty Teoretyczne Rachunkowości. 2010; 55 (111), 59-74.

7. Fijałkowska B. Indeks Zdrowia Finansowego jako termometr w podmiotach leczniczych. Finanse, Rynki Finansowe, Ubezpieczenia. 2017 Nr 5: 521-529.

8. Korol T. Narzędzia analizy wskaźnikowej. Nowe podejście do analizy wskaźnikowej w przedsiębiorstwie. Warszawa: Wolters Kluwer Polska 2013: 24-31. 
9. Kowalska S. Znaczenie płynności finansowej w zarządzaniu przedsiębiorstwem w sytuacjach kryzysowych. Zeszyty Naukowe Uniwersytetu Szczecińskiego. Finanse. Rynki Finansowe. Ubezpieczenia. 2013 Nr 58: 223-230.

10. Warelis A. Użyteczność mierników oceny kondycji finansowej szpitalnictwa. Zeszyty Naukowe Uniwersytetu Szczecińskiego. Finanse, Rynki Finansowe, Ubezpieczenia. $2011 \mathrm{Nr}$ 44: 183-197.

11. Wiercińska A. Specyfika zarządzania finansami szpitala. Zarządzanie i Finanse. 2014; 12 (2): 5-20.

12. Prędkiewicz K, Prędkiewicz P. Płynność finansowa szpitali samorządowych w Polsce - wyniki badań empirycznych. Zeszyty naukowe Uniwersytetu Szczecińskiego. Finanse Rynki Finansowe, Ubezpieczenia. 2013 Nr 62: 170-179.

13. Łagowski P. Analiza finansowa kluczowych podmiotów leczniczych w województwie dolnośląskim. Wydział Prawa, administracji i Ekonomii Uniwersytetu Wrocławskiego. Finanse i Rachunkowość. 2016 Nr 2: 135-149.
14. https://pl.bffgroup.com/publikacje-i-inne-dokumenty

Received: 05.07.2019

Accepted for publication: 20.08.2019

Otrzymano: 5.07.2019 r.

Zaakceptowano do publikacji: 20.08.2019 r.

\section{Address for correspondence:}

Adres do korespondencji

Dominik Maślach

Medical University of Bialystok

Department of Public Health

ul. Szpitalna 37

15-295 Białystok

Phone: +48 856865055

E-mail address: dominikm@umb.edu.pl 